\title{
SCIENTIFIC REPORTS

\section{Chemical production of acidified activated carbon and its influences on soil fertility comparative to thermo-pyrolyzed biochar}

\begin{abstract}
Haider Sultan ${ }^{2}$, Niaz Ahmed $^{1}$, Muhammad Mubashir ${ }^{4}$ \& Subhan Danish ${ }^{1,3^{*}}$
Biochar $(B C)$ is gaining attention day by day due to its potential benefits for the improvement in degraded soil health. During its production by pyrolysis, carbon sequestration is an important aspect that makes it environment-friendly amendment. However, $100 \%$ anaerobic combustion of waste at such a high temperature decreases its adaptability to produce BC at commercial scale. On the other hand, the alkaline nature of $B C$ also causes adverse effects on soil health when used in alkaline soils. Keeping in mind the problem of $\mathrm{BC}$ production and its high $\mathrm{pH}$, current experiment was conducted to introduce chemical production of acidified activated carbon (AAC) and its effects on soil nutrients status comparative to high temperature pyrolyzed BC. As compared to thermal pyrolysis, sulphuric acid produce acidified activated carbon in minimum time and large in quantity. Sulphuric acid produces acidified activated carbon, fix higher carbon as compared to thermal pyrolyzed BC. Results also showed that application of $2 \%$ AAC was far better for decreasing alkaline soil pHs (3.52 and 4.71\%) and ECe (45.2 and 71.4\%) as compared to control in clay and sandy clay loam. A significant maximum increase in available $P$ (117.5 and 25.9\%), extractable $Z n$ (42.0 and 52.2\%), B (111.4 and 46.2\%) and Fe (59.5 and $34.4 \%$ in clay and sandy clay texture soils also validated the efficacious functioning of AAC over BC and control. It is concluded that sulphuric acid use is an easier and adaptable method to produce activated carbon at commercial scale. As compared to thermal pyrolyzed BC, application of AAC could be more effective in the improvement of soil health and fertility status.
\end{abstract}

Role of agriculture in food production is immense ${ }^{1}$ to fulfil the hunger of human's ${ }^{2}$. Today modern agriculture is feeding more than 6000 millions of people, compared to old age hunter-gatherer lifestyle (that provide food to 4 million people $)^{3}$. Owing to modern production technologies e.g. use of inorganic fertilizers, pesticides, organic amendments, biofertilizers and genetically modified high yield varieties, the production of crops has become double in the last 40 years ${ }^{1,4,5}$. This change in food demand and supply ${ }^{6}$ has shifted the conventional agriculture towards the intensive cultivation of crops ${ }^{7}$. However, intensive cultivation of crops not only depleted the concentration of the nutrients but also has degraded the soil health. Owing to high soil $\mathrm{pH}$, low organic matter and poor microbial population, now crops are suffering from hidden hunger of macro and micronutrients ${ }^{5,7,8}$. To describe such a low concentration of macro and micronutrients bioavailability, poor soil fertility is a general term which is commonly used ${ }^{9}$. Since the early years of the $21^{\text {st }}$ century, the demand and application of inorganic fertilizers were increased tremendously to solve the problem of poor soil fertility ${ }^{10}$. It is documented fact that the application of inorganic fertilizers is the necessity of time to get the maximum yield of crops. However, these fertilizers are also costing a lot in terms of negative effects as well i.e., development of salinity problem ${ }^{11}$ in soil due to their enrich application ${ }^{12}$. Overuse of nitrogen and phosphorus fertilizers where increased crops productivity, they also have destroyed natural soil ecosystem ${ }^{13,14}$. Out of total applied nitrogen fertilizers, plants only consumed $50 \%$ while remaining $2-20 \%$ is lost due to its volatile nature as $\mathrm{NH}_{4}, 15-25 \%$ chemically reacted with organic fractions and clay soil particle and $2-10 \%$ become part of water ${ }^{15}$. However, among micronutrients, the

${ }^{1}$ Department of Soil Science, Faculty of Agricultural Sciences \& Technology, Bahauddin Zakariya University, Multan, 60800, Punjab, Pakistan. ${ }^{2}$ College of Biology and Environment, Nanjing Forestry University, Nanjing, 210037, Jiangsu, China. ${ }^{3}$ Soil and Water Testing Laboratory, PakArab Fertilizer Limited, Khanewal Road, Multan, Punjab, Pakistan. ${ }^{4}$ Soil \& Water Testing Laboratory for Research, Bahawalpur, 63100, Punjab, Pakistan. *email: sd96850@ gmail.com 


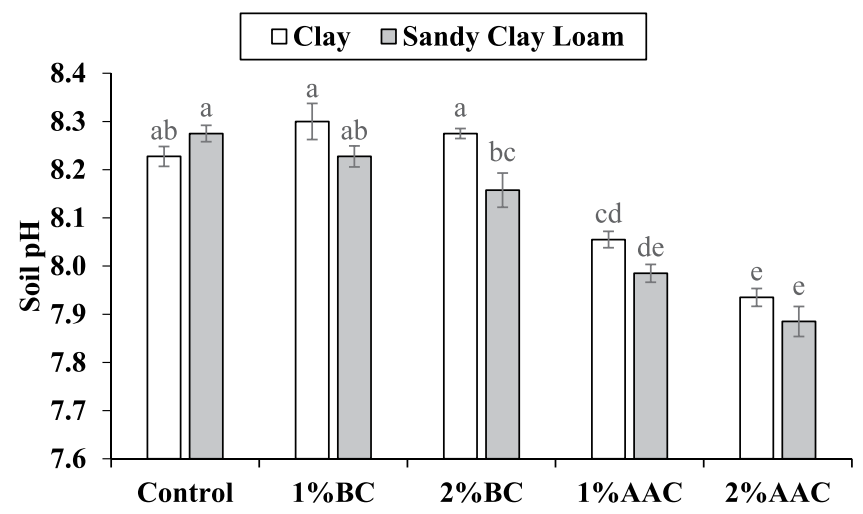

Figure 1. Effect of various levels of thermo pyrolyzed BC and chemically acidified activated carbon on clay and sandy clay loam textured soil $\mathrm{pH}$. Error bars represents standard error calculated through 3 replicates of each treatment.

deficiency of $\mathrm{Zn}$ is another critical problem in alkaline calcareous soils which resulted in a significant reduction of yield ${ }^{16-20}$. An elevated level of $\mathrm{P}$ concentration in soil is also considered an important factor for the immobilization of $\mathrm{Zn}$ compared to high $\mathrm{pH}^{21}$. Enrichment of lakes with phosphorus due to its high rate of application is also causing eutrophication ${ }^{22}$. It has been observed that the deficiency of Fe also resulted in the chlorosis especially in citrus, deciduous fruits and leguminous crops ${ }^{23,24}$. The deficiency of boron has also played an imperative role in the deterioration of food quality ${ }^{25-27}$. Similarly, industries that are involved in the production of inorganic fertilizers are significantly contributing to heavy metals $(\mathrm{Hg}, \mathrm{As}, \mathrm{Cd}, \mathrm{Pb}, \mathrm{Ni}$, and $\mathrm{Cu})$ accumulation and contamination $^{28}$. So far, many scientists have made attempts to resolve the problems of high soil $\mathrm{pH}$ and low organic matter by using organic amendments i.e., farmyard manure, compost and green manuring ${ }^{29}$. But their susceptibility towards decomposition is a major drawback. On the other hand, scientists also remained successful to tackle the problem of organic residues quick decomposition by introducing biochar (BC). Biochar is nutrients enrich environment-friendly organic amendment that is resistant against decomposition, decrease the emission of greenhouse gases (GHG's) and sequester stable carbon ${ }^{30}$. Application of BC can significantly decrease the loss of nutrients by increasing soil $\mathrm{CEC}^{31}$. However, high $\mathrm{pH}$ of $\mathrm{BC}$ is again a major hurdle in the way to optimize the nutrients use efficiency, especially in high $\mathrm{pH}$ soils ${ }^{32}$. On the basis of $\mathrm{BC} \mathrm{pH}$, the buffering capacity of the soil is also increased towards change in soil $\mathrm{pH}^{33}$. The necessity of time is to make acidified BC. Although it is a very difficult task when produced at a commercial scale due to its high buffering ability. Keeping in mind the problems of low soil nutrients availability despite the presence of high immobile pool and high $\mathrm{pH}$ of biochar current experiment was conducted to introduce a chemical method for production acidified activated carbon (AAC). The aim of the current study was to introduce chemically carbon sequestration method for bulk production of AAC without using such a higher temperature. It is hypothesized that the use of the chemical method for production of AAC could be easier to adopt commercially, time-saving and less economic technique as compared to thermal pyrolysis.

\section{Results}

Soil $\mathrm{pH}_{s^{*}} \quad$ Both main and interactive effects of various soil texture (ST) and treatments (T) were significant on the $\mathrm{pH} s$ of soil. No significant change was noted in soil $\mathrm{pH} s$ where $1 \%$ and $2 \% \mathrm{BC}$ were applied as compared to control in clay. Addition of $1 \%$ BC was statistically alike in clay soil but $2 \%$ BC differed significantly in sandy clay loam for soil $\mathrm{pH} s$ as compared to control. It was observed that $1 \%$ and $2 \%$ AAC significantly decreased soil $\mathrm{pH} s$ over control in clay and sandy clay loam. Application of $2 \%$ AAC significantly decreased the soil $\mathrm{pH} s$ as compared to $1 \%$ AAC in clay soil (Fig. 1). However, $1 \%$ and $2 \%$ ACC remained statistically alike to each other in sandy clay loam soil. The maximum reduction of 3.52 and $4.71 \%$ in soil $\mathrm{pHs}$ was noted in $2 \%$ AAC over control in clay and sandy clay loam respectively.

Soil EC $e_{e} \quad$ Both main and interactive effects of various soil texture (ST) and treatments (T) were significant on ECe of soil. For soil ECe, the addition of $1 \%$ and $2 \% \mathrm{BC}$ and AAC remained statically alike to each other but differed significantly as compared to control. Application of $1 \%$ and $2 \%$ BC significantly enhanced soil ECe over control in clay soil. However, $1 \%$ and $2 \%$ AAC significantly decreased soil ECe over control in clay soil. In sandy clay loam, no significant change in ECe was observed among control and 1\% BC. However, 2\% BC significantly increased ECe of sandy clay loam soil as compared to control. In addition, $1 \%$ and $2 \%$ AAC also remained statistically alike to each other and with control for soil ECe (Fig. 2). The maximum increase of 45.2 and $71.4 \%$ in soil ECe was noted where $2 \% \mathrm{BC}$ was applied as compared to control in clay and sandy clay loam respectively. However, the application of $2 \%$ AAC gave the maximum reduction of $36.7 \%$ in soil ECe over control in clay soil.

Soil phosphorus. Both main and interactive effects of various soil texture (ST) and treatments (T) were significant on soil phosphorus (P). Application of $1 \%$ and $2 \%$ BC and AAC significantly improved the soil available $\mathrm{P}$ as compared to control in clay soil. For improvement in soil available P, 2\% BC and AAC remained significantly better as compared to $1 \% \mathrm{BC}$ and AAC in clay soil. No significant change in soil available $\mathrm{P}$ in clay soil was noted 


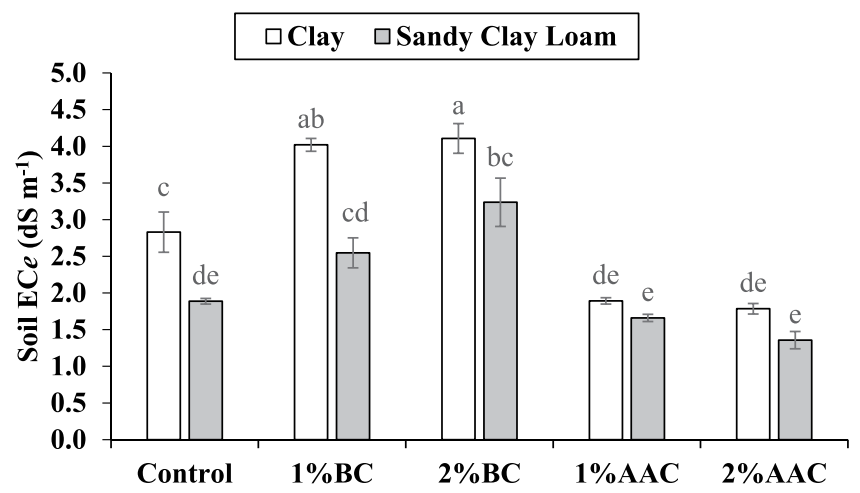

Figure 2. Effect of various levels of thermo pyrolyzed BC and chemically acidified activated carbon on clay and sandy clay loam textured soil ECe. Error bars represents standard error calculated through 3 replicates of each treatment.

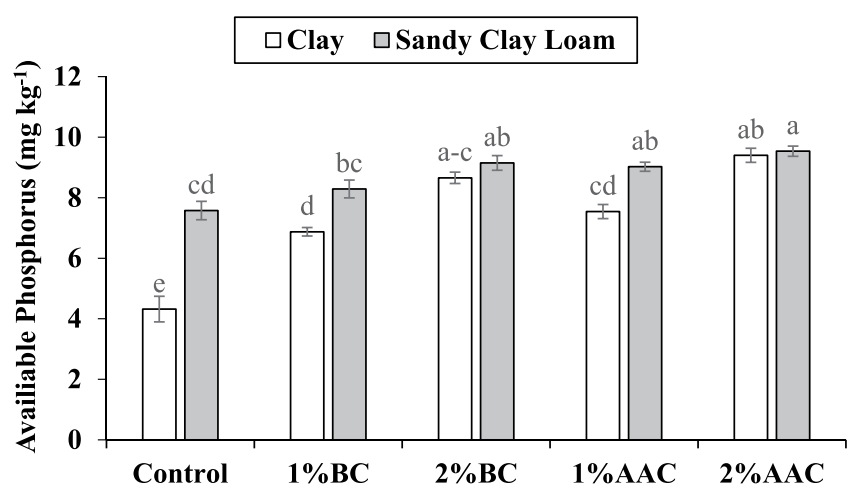

Figure 3. Effect of various levels of thermo pyrolyzed BC and chemically acidified activated carbon on clay and sandy clay loam textured soil available phosphorus. Error bars represents standard error calculated through 3 replicates of each treatment.

where $1 \%$ BC and 1\% ACC were applied. Similarly, 2\% BC and 2\% AAC also remained statistically similar to each other for available soil $\mathrm{P}$ in clay soil. In case of sandy clay loam, $2 \% \mathrm{BC}$ was significantly better as compared to control for available soil P. No significant change was noted among $1 \% \mathrm{BC}$ and control for soil available $\mathrm{P}$ in sandy clay loam. However, $1 \% \mathrm{BC}$ and $2 \% \mathrm{BC}$ remained statistically alike to each other for available soil P in sandy clay loam (Fig. 3). It was observed that application of both $1 \%$ and $2 \%$ AAC performed significantly better as compared to control for available soil P. Application of $1 \%$ and $2 \% \mathrm{BC}$ and AAC remained statistically alike to each other for available soil $\mathrm{P}$ in sandy clay loam. The maximum increase of 117.5 and $25.9 \%$ in soil available $\mathrm{P}$ was observed in clay and sandy clay loam respectively.

Soil potassium. Both main and interactive effects of various soil texture (ST) and treatments (T) were significant on soil extractable potassium (K). No significant change was observed among $2 \% \mathrm{BC}, 2 \% \mathrm{AAC}, 1 \% \mathrm{BC}$, $1 \% \mathrm{AAC}$ and control for extractable $\mathrm{K}$ in clay. In the case of sandy clay loam, application of $2 \% \mathrm{BC}$ and $2 \%$ AAC remained significantly better over control for extractable $\mathrm{K}$. Both $1 \% \mathrm{BC}$ and $1 \%$ AAC were statistically alike to each other and with control for extractable $\mathrm{K}$ in sandy clay loam (Fig. 4). Similarly, 2\% BC and 2\% AAC also remained statistically alike to each other for extractable $\mathrm{K}$ in sandy clay loam. The maximum increase of $60.6 \%$ in extractable $\mathrm{K}$ was noted over control where $2 \%$ AAC was applied in sandy clay loam.

Soil zinc. Both main and interactive effects of various soil texture (ST) and treatments (T) were significant on soil extractable zinc $(\mathrm{Zn})$. Application of $2 \%$ AAC remained significantly better as compared to control for soil extractable $\mathrm{Zn}$ in clay. It was noted that $1 \% \mathrm{AAC}, 1 \% \mathrm{BC}$ and $2 \% \mathrm{BC}$ were statistically alike to each other but only $1 \%$ AAC and $2 \%$ BC remained significantly better as compared to control for soil extractable $\mathrm{Zn}$ in clay. Application of $1 \% \mathrm{BC}$ was statistically similar to control for soil extractable $\mathrm{Zn}$ in clay. In case o0f sandy clay loam, $2 \% \mathrm{BC}$ and $2 \% \mathrm{AAC}$ performed significantly better as compared to control for soil extractable Zn. No significant change was observed among $1 \%$ AAC and $1 \%$ BC for soil extractable $\mathrm{Zn}$ in sandy clay loam. It was observed that $2 \% \mathrm{BC}$ was statistically alike but $2 \%$ AAC differed significantly as compared to $1 \%$ AAC for soil extractable $\mathrm{Zn}$ in sandy clay loam (Fig. 5). However, $1 \%$ AAC and 1\% BC remained significantly better over control for soil extractable $\mathrm{Zn}$ in sandy clay loam. The maximum increase of 42.0 and $52.2 \%$ in soil extractable $\mathrm{Zn}$ in sandy clay loam was observed as compared to control where $2 \% \mathrm{AAC}$ was applied in clay and sandy clay loam respectively. 


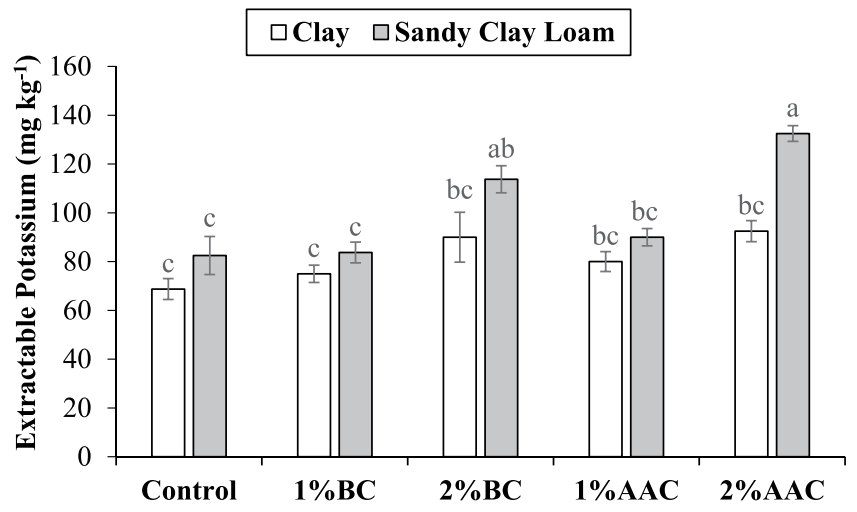

Figure 4. Effect of various levels of thermo pyrolyzed BC and chemically acidified activated carbon on clay and sandy clay loam textured soil extractable potassium. Error bars represents standard error calculated through 3 replicates of each treatment.

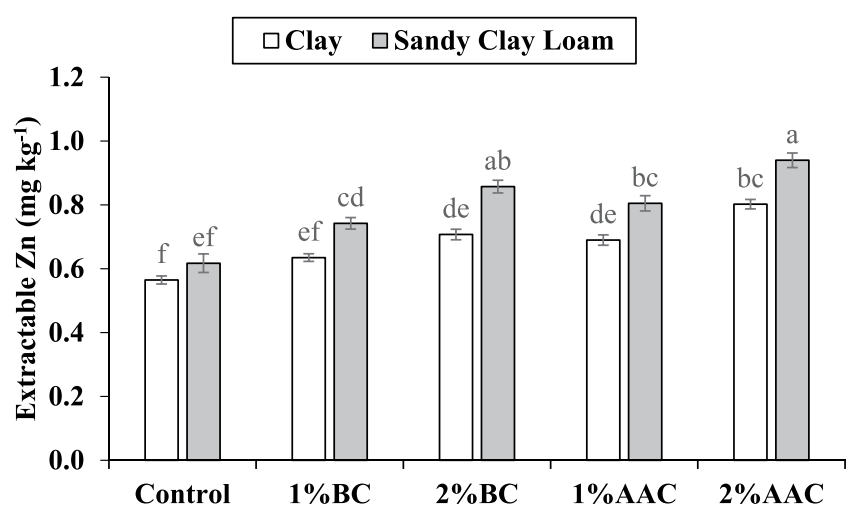

Figure 5. Effect of various levels of thermo pyrolyzed BC and chemically acidified activated carbon on clay and sandy clay loam textured soil extractable zinc. Error bars represents standard error calculated through 3 replicates of each treatment.

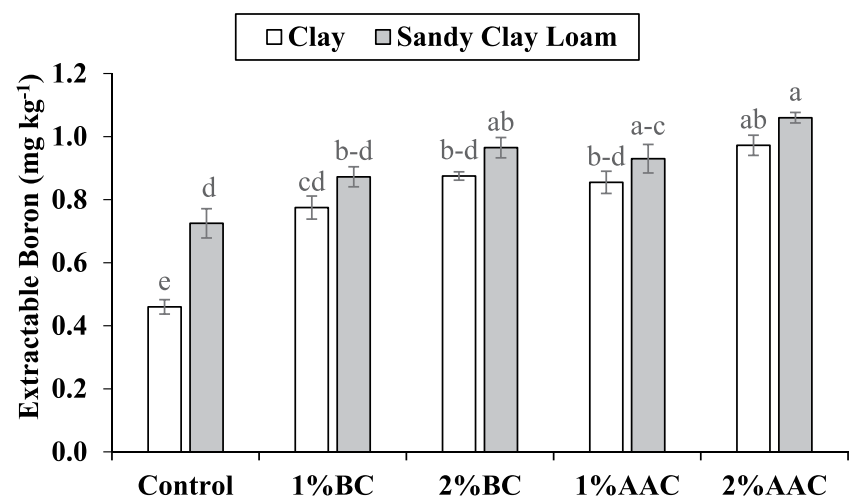

Figure 6. Effect of various levels of thermo pyrolyzed BC and chemically acidified activated carbon on clay and sandy clay loam textured soil extractable boron. Error bars represents standard error calculated through 3 replicates of each treatment.

Soil boron. Both main and interactive effects of various soil texture (ST) and treatments (T) were significant on soil extractable B. Application of $2 \%$ BC, $1 \%$ AAC and $2 \%$ AAC were statistically alike to each other but differed significantly as compared to control for soil extractable B in clay. No significant change was noted among $1 \% \mathrm{BC}, 2 \% \mathrm{BC}$ and $1 \% \mathrm{AAC}$ for soil extractable B in clay. However, $2 \% \mathrm{BC}$ remained significantly better as compared to $1 \% \mathrm{BC}$ for soil extractable $\mathrm{B}$ in clay. In addition, $1 \% \mathrm{BC}$ also differed significantly for soil extractable $\mathrm{B}$ over control in clay soil. In the case of sandy clay loam, application of $1 \% \mathrm{BC}, 2 \% \mathrm{BC}, 1 \% \mathrm{AAC}$ and $2 \%$ AAC were statistically similar to each other from control for soil extractable B (Fig. 6). However, 2\% BC, 1\% AAC and 2\% 


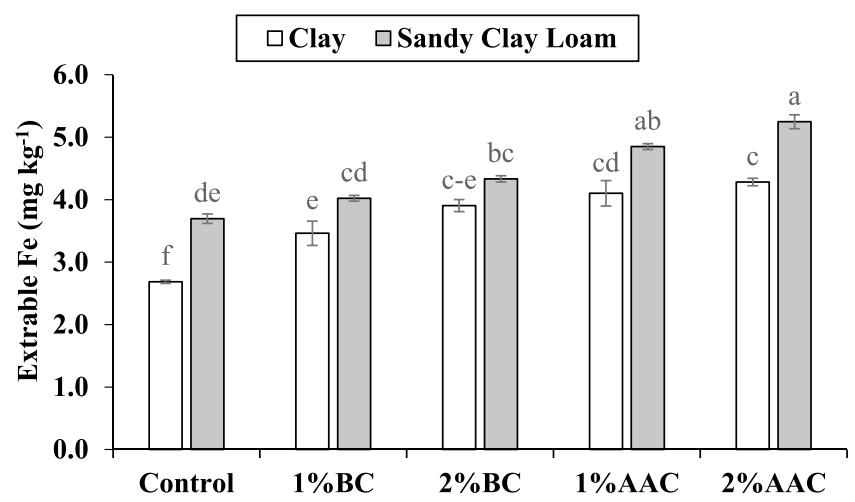

Figure 7. Effect of various levels of thermo pyrolyzed BC and chemically acidified activated carbon on clay and sandy clay loam textured soil extractable iron. Error bars represents standard error calculated through 3 replicates of each treatment.

\begin{tabular}{|c|c|c|c|c|c|}
\hline BC & Unit & Value & AAC & Unit & Value \\
\hline $\mathrm{pH}$ & - & 4.11 & $\mathrm{pH}$ & - & 8.03 \\
\hline $\mathrm{EC}_{e}$ & $\mathrm{dS} \mathrm{m}^{-1}$ & 1.83 & $\mathrm{EC}_{e}$ & $\mathrm{dS} \mathrm{m^{-1 }}$ & 2.11 \\
\hline Volatile Matter & $\%$ & 10.90 & Volatile Matter & $\%$ & 12.29 \\
\hline Ash Content & $\%$ & 13.10 & Ash Content & $\%$ & 40.26 \\
\hline Fixed Carbon & $\%$ & 76.00 & Fixed Carbon & $\%$ & 47.45 \\
\hline Total N & $\%$ & 0.95 & Total $\mathrm{N}$ & $\%$ & 0.16 \\
\hline Total P & $\%$ & 0.66 & Total P & $\%$ & 0.43 \\
\hline Total K & $\%$ & 2.09 & Total K & $\%$ & 1.66 \\
\hline Total Ca & $\%$ & 4.21 & Total $\mathrm{Ca}$ & $\%$ & 3.96 \\
\hline Total $\mathrm{Na}$ & $\%$ & 0.61 & Total Na & $\%$ & 0.59 \\
\hline Total Zn & $\mathrm{mg} \mathrm{kg}^{-1}$ & 0.10 & Total Zn & $\mathrm{mg} \mathrm{kg}^{-1}$ & 0.13 \\
\hline Total B & $\mathrm{mg} \mathrm{kg}^{-1}$ & 0.17 & Total B & $\mathrm{mg} \mathrm{kg}^{-1}$ & 0.22 \\
\hline Total Fe & $\mathrm{mg} \mathrm{kg}^{-1}$ & 1.12 & Total Fe & $\mathrm{mg} \mathrm{kg}^{-1}$ & 1.01 \\
\hline
\end{tabular}

Table 1. Characteristics of thermo pyrolyzed biochar (BC) and acidified activated carbon (AAC).

AAC differed significantly from control for soil extractable B in sandy clay loam. No significant change was noted in soil extractable B over control in 1\% BC. The maximum increase of 111.4 and $46.2 \%$ in soil extractable B was noted in $2 \%$ AAC over control in clay and sandy clay loam respectively.

Soil iron. Both main and interactive effects of various soil texture (ST) and treatments (T) were significant on soil extractable iron (Fe). Application of $2 \%$ BC, $1 \%$ AAC and $2 \%$ AAC were statistically alike to each other but differed significantly as compared to control for soil extractable Fe in clay. No significant change was noted among $2 \% \mathrm{BC}$ and $1 \% \mathrm{BC}$ for soil extractable Fe in clay soil. It was noted that $1 \% \mathrm{BC}$ also remained significantly different as compared to control in clay for soil extractable Fe. For sandy clay loam, $1 \%$ and $2 \%$ AAC were statistically similar to each other but differed significantly as compared to control for extractable Fe (Fig. 7). Similarly, no significant change was noted among $1 \% \mathrm{BC}$ and $2 \% \mathrm{BC}$ but only $2 \% \mathrm{BC}$ remained significantly better from control for extractable Fe in sandy clay loam. The maximum increase of 59.5 and 34.4\% in extractable soil Fe was noted over control where $2 \% \mathrm{AAC}$ was applied as a treatment in clay and sandy clay loam respectively.

\section{Discussion}

In the current study, the application of $\mathrm{BC}$ significantly increased the $\mathrm{pH} s$ of soil. This increase in soil $\mathrm{pH} s$ was due to high $\mathrm{pH}$ of $\mathrm{BC}$. Presence of alkaline mineral elements was the possible reason for the high $\mathrm{pH}$ of $\mathrm{BC}$ (Table 1). Biochar addition in soil significantly enhanced the soil ECe possibility due to the release of mineral nutrients (soluble base cations $\mathrm{K}^{+}$and $\mathrm{Ca}^{++}$and $\mathrm{Na}^{+}$) in soil solution and exchange with soil exchange sites. Pre-experimental analysis of $\mathrm{P}, \mathrm{K}$ and $\mathrm{Ca}$ in $\mathrm{BC}$ (Table 1) validated our argument regarding a significant increase in soil EC. A significant amount of presence of mineral nutrients in BC structure is well documented by many scientists ${ }^{5,34,35}$. Abid et al..$^{34}$ also reported similar kind of significant increase in soil $\mathrm{pH}$ when they applied BC in soil under various sources of irrigation. During pyrolysis oxygen-containing functional groups and alkaline ash, contents are increased on the surface of $\mathrm{BC}$ that played an imperative role in the enhancement of soil $\mathrm{pH}^{36}$. According to Yuan et al. ash content of BC may have $48-330 \mathrm{cmol} \mathrm{kg}{ }^{-1}$ soluble base cations $\left(\mathrm{K}^{+}, \mathrm{Ca}^{++}, \mathrm{Mg}^{++}\right.$, and $\mathrm{Na}^{+}$). On the other hand, the presence of $\mathrm{Ca}^{++}, \mathrm{Mg}^{++}$and $\mathrm{K}^{+}$in large amount easily replace the $\mathrm{H}^{+}$ions in soil solution, thus, resulted in an increase of soil $\mathrm{pH}^{37}$. However, AAC significantly decreased the soil $\mathrm{pH} s$ might be due to the presence of $\mathrm{H}_{2} \mathrm{SO}_{4}$ in the pore spaces. The molecules of $\mathrm{H}_{2} \mathrm{SO}_{4}$ possibility become the part 
of soil solution when the soil was irrigated. Enrichment of $\mathrm{H}^{+}$ions by $\mathrm{H}_{2} \mathrm{SO}_{4}$ decreased the soil $\mathrm{pH}$ significantly. Furthermore, higher amount of $\mathrm{Ca}$ in calcareous soil might react with $\mathrm{SO}_{4}$ which make $\mathrm{CaSO}_{4}$ that is well documented regarding aaleviation of adverse effects of $\mathrm{Na}$. In addition, AAC would be the major cause of an increase in the buffering ability of soil to sustain low $\mathrm{pH}$ for a long time (60 days). Reduction in soil EC by AAC might also be due to sorption of minerals by empty exchange sites, possibly produced due to the release of $\mathrm{H}_{2} \mathrm{SO}_{4}$ in soil. Low $\mathrm{pH}$ of soil played an imperative role in the solubilization of immobile soil P. According to Hopkins and Ellsworth ${ }^{38}$ reduction in soil $\mathrm{pH}$ (6.5) increase the mobility of fixed soil P. Under low soil $\mathrm{pH}$, the activity of $\mathrm{H}^{+}$ dissociates the linkage of calcium and phosphorus in calcareous parent material soils. The breakage of the bond between calcium and $\mathrm{P}$ resulted in dissolution and availability of immobile $\mathrm{P}$ in soil solution ${ }^{39}$. In addition, $\mathrm{P}$ is also the part of $\mathrm{BC}$ structure as well ${ }^{40}$. Reduction in $\mathrm{pH}$ of biochar also increases the release of $\mathrm{P}$ from biochar into soil solution ${ }^{41}$ as observed in AAC of the current study. Indirectly BC application also facilitates the soil microbes to secrete phosphomonoesterase that enhances the soil $\mathrm{P}$ mineralization ${ }^{42}$. In the current study, improvement in micronutrients, $\mathrm{Zn}, \mathrm{B}$ and $\mathrm{Fe}$ might also be associated with the reduction in soil $\mathrm{pH}$ and improvement in cation exchange sites of soil. According to Laird ${ }^{43}$ application of BC can increase $20 \%$ cation exchange capacity (CEC) of soil. This CEC is an indirect measure which enhanced water and nutrients retention by decreasing its leaching loss. Higher surface area and the carboxyl group of BC play an imperative role in increasing the CEC of soil and nutrients availability ${ }^{44}$.

\section{Conclusion}

In conclusion, sulphuric acid use is an easier and adaptable method to produce activated carbon at commercial scale. Thermal pyrolyzed BC due to high $\mathrm{pH}$ is less efficacious than AAC for improvement in soil health and fertility status. More investigations are needed to introduce AAC as an effective replacement of BC optimum utilization of micro and macronutrients in soil.

\section{Materials and Methods}

An incubation experiment was conducted in Soil and Water Testing Laboratory for Research Multan. The treatments were control (no BC and no AC), $1 \%$ biochar (1\% BC), $2 \%$ biochar ( $2 \% \mathrm{BC}), 1 \%$ acidic activated carbon ( $1 \% \mathrm{AAC}), 2 \%$ acidic activated carbon ( $2 \% \mathrm{AAC}$ ) applied in two different texture of soil (clay and sandy clay loam).

For the production of thermo pyrolyzed biochar (BC), sugarcane waste syrup was collected from the sugar mill. After oven drying at $65^{\circ} \mathrm{C}$, clods like the structure of syrup was collected and pyrolyzed in partially aerobic pyrolyzer at $550^{\circ} \mathrm{C}$ for $75 \mathrm{~min}^{5}$. Finally, prepared $\mathrm{BC}$ was grinded and passed through sieve $2 \mathrm{~mm}$ sieve and stored in airtight plastic jars for further experimentation.

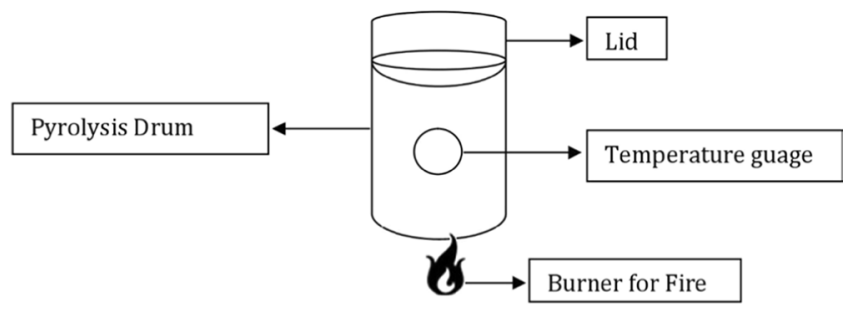

For the very first chemically acidified activated carbon (AAC) was prepared by using sugarcane waste syrup of sugar mill. Syrup waste was taken in a specially designed reactor. After that concentrated (98\%) sulphuric acid $\left(\mathrm{H}_{2} \mathrm{SO}_{4}\right)$ was added in the reactor $(2: 1, \mathrm{v} / \mathrm{v})$. A vigorous reaction takes place in which water was evaporated from the waste syrup of sugar mill leaving behind acidic activated carbon (AAC).

$$
\text { Carbohydrates }\left(\mathrm{CH}_{2} \mathrm{O}\right)+\mathrm{H}_{2} \mathrm{SO}_{4} \text { (acidifying and dehydrating agent) }=\mathrm{AAC}+\mathrm{H}_{2} \mathrm{O}
$$

Biochar $\mathrm{pH}$ and $\mathrm{EC}$ were determined in $\mathrm{BC}$ and $\mathrm{AAC}$ by making water ratio of $1: 20 \mathrm{w} / \mathrm{v}^{32}$. Digestion of $\mathrm{BC}$ and $\mathrm{AAC}$ was done by using di-acid mixture $\mathrm{HNO}_{3}: \mathrm{HClO}_{4}$ in $2: 1$ ratio ${ }^{45}$. The yellow colour method was followed for total phosphorus (P) analysis in BC and AAC on a spectrophotometer ${ }^{46}$. Potassium concentration in $\mathrm{BC}$ and AAC was measured on flamephotometer ${ }^{47}$. For analysis of nitrogen on Kjeldahl's distillation apparatus ${ }^{48}, \mathrm{H}_{2} \mathrm{SO}_{4}$ digestion ${ }^{46}$ was followed. Ash content $(\mathrm{AC})$ and volatile matter (VM) in BC and AAC were determined by heating the sample in a muffle furnace at $550^{\circ} \mathrm{C}$ and $450^{\circ} \mathrm{C}$ respectively ${ }^{49}$. The fixed carbon in $\mathrm{BC}$ and AAC was calculated using the equation Noor et al. ${ }^{50}$ :

$$
\text { Fixed Carbon }(\%)=100-(\% \text { Volatile Matter }+\% \text { Ash Content })
$$

The characteristics of BC and AAC are given in Table 1.

For incubation of soil, small clay pots were used. In each pot, $1 \mathrm{~kg}$ of soil was added along with BC and AAC as per treatment plan. The moisture of soil was maintained $65 \%$ on w/w basis throughout the incubation of 60 days. After 60 days all the soil samples were initially air dried and then passed through $2 \mathrm{~mm}$ nylon sieve for their analysis.

For determination of $\mathrm{pH}_{s}$ and $\mathrm{EC}_{e}$ of soil Schofield and Taylor ${ }^{51}$ and US Salinity Laboratory Staff ${ }^{52}$ were followed respectively. Extractable soil phosphorus was analyzed by Olsen and Sommers ${ }^{53}$ methodology. Nadeem et $a l .{ }^{47}$ method was followed for determination of extractable soil K. Boron in soil samples were analyzed according 
to Bingham ${ }^{54}$ on a spectrophotometer using Azomethine-H. Micronutrients zinc $(\mathrm{Zn})$ and iron $(\mathrm{Fe})$ were analyzed on atomic absorption spectrophotometer according to the methodology of Lindsay and Norvell ${ }^{55}$.

Statistical analysis was done according to the standard statistical procedure of Steel et al. ${ }^{56}$. Descriptive statistical analysis and analysis of variance (ANOVA) was applied on data to find significance. Means were compared by Tukey's test and correlation was find at the $p \leq 0.05$ level $^{47}$.

\section{Data availability}

No datasets were generated or analyzed during the current study. All the analyzed data can be accessed after publication by requesting to the corresponding author.

Received: 19 June 2019; Accepted: 19 December 2019;

Published online: 17 January 2020

\section{References}

1. Tilman, D., Cassman, K. G., Matson, P. A., Naylor, R. \& Polasky, S. Agricultural sustainability and intensive production practices. Nature 418, 671-677 (2002).

2. Alexandratos, N. World food and agriculture: Outlook for the medium and longer term. Proc. Natl. Acad. Sci. 96, 5908-5914 (1999).

3. Cohen, J. E. How Many People Can the Earth Support? WW Norton \& Company (1995).

4. Farrell, M., Macdonald, L. M., Butler, G., Chirino-Valle, I. \& Condron, L. M. Biochar and fertiliser applications influence phosphorus fractionation and wheat yield. Biol. Fertil. Soils 50, 169-178 (2014).

5. Tahir, F. A., Ahamad, N., Rasheed, M. K. \& Danish, S. Effect of various application rate of zinc fertilizer with and without fruit waste biochar on the growth and Zn uptake in maize. Intl. J. Biosci. 13, 159-166 (2018).

6. FAO. Food and Agriculture Organization of the United Nations (FAO). (2001).

7. Sarma, P. K. et al. Effect of Foliar Application of Potassium on Yield, Drought Tolerance and Rain Water Use Efficiency of Toria under Rainfed Upland Situation of Assam. Indian. J. Dryl. Agric. Res. Dev. 30, 55-59 (2015).

8. Cordell, D. \& White, S. Tracking phosphorus security: indicators of phosphorus vulnerability in the global food system. Food Security 7, 337-350 (2015).

9. Jianping, Z. Soil erosion in Guizhou province of China: A case study in Bijie prefecture. Soil. Use Manag. 15, 68-70 (1999).

10. Hasina, G., Said, A., Saeed, B., Mohammad, F. \& Ahmad, I. Effect of foliar application of nitrogen, potassium and zinc on wheat growth. ARPN J. Agric. Biol. Sci. 6, 56-58 (2011).

11. Wu, F. Z., Zhao, F. Y. \& Liu, Y. Y. Analysis of the problems in continues cropping system of protective vegetable and the controlling ways. In Fertilizing for Sustainable Production of High Quality Vegetables. (eds. Li, X. L., Zhang, F. S. \& Mi, G. H.) 157-163 (China Agricultural University Publisher, 2000).

12. Bockman, O. C., Kaarstad, O., Lie, O. H. \& Richards, I. Agriculture and Fertilizers. (Agricultural Group, Norsk Hydro A.S, 1990).

13. Vitousek, P. M., Mooney, H. A., Lubchenco, J. \& Melillo, J. M. Human domination of Earth's ecosystems. In Urban Ecology: An International Perspective on the Interaction Between Humans and Nature 3-13 (2008). 10.1007/978-0-387-73412-5_1

14. Carpenter, S. R. et al. Nonpoint Pollution of Surface Waters with Phosphorus and Nitrogen. Issues Ecol. 8, 559-568 (1998).

15. Sönmez, İ., Kaplan, M. \& Sönmez, S. Kimyasal gübrelerin çevre kirliliği üzerine etkileri ve çözüm önerileri'. Batı Akdeniz Tarımsal Araștırma Enstitüsü Derim Derg. 25, 24-34 (2008).

16. Tandon, H. L. S. Micronutrients in Soils, Crops, and Fertilizers. In Fertilizer Development and Consultation Organization (1995).

17. Cakmak, I. et al. Zinc deficiency as a critical problem in wheat production in Central Anatolia. Plant. Soil. 180, 165-172 (1996).

18. Rashid, A., Kausar, M. A., Hussain, F. \& Tahir, M. Alleviating Zinc Deficiency in Transplanted Flooded Rice Grown in Alkaline Soils of Pakistan. Int. Rice Res. Notes 24, 32-33 (1999).

19. Kumar Singh, A. et al. Effect of Sulphur and Zinc on Rice Performance and Nutrient Dynamics in Plants and Soil of Indo Gangetic Plains. J. Agric. Sci. 4, 162-170 (2012).

20. Quijano-Guerta, C., Kirk, G. J. D., Portugal, A. M., Bartolome, V. I. \& McLaren, G. C. Tolerance of rice germplasm to zinc deficiency. F. Crop. Res. 76, 123-130 (2002).

21. Mortvedt, J. J., Cox, F. R., Shuman, L. M. \& Welch, R. M. Micronutrients in Agriculture. (Soil Sci. Soc. Amer., 1991).

22. Bennett, E. M., Carpenter, S. R. \& Caraco, N. F. Human Impact on Erodable Phosphorus and Eutrophication: A Global Perspective Increasing accumulation of phosphorus in soil threatens rivers, lakes, and coastal oceans with. Source Biosci. 51, 227-234 (2001).

23. Rashid, A., Rafique, E., Din, J., Malik, S. N. \& Arain, M. Y. Micronutrient deficiencies in rainfed calcareous soils of Pakistan. I. Iron chlorosis in peanut. Commun. Soil. Sci. Plant. Anal. 28, 135-148 (1997).

24. Saxena, M. C., Malhotra, R. S. \& Singh, K. B. Iron deficiency in chickpea in the Mediterranean region and its control through resistant genotypes and nutrient application. Plant. Soil. 23, 251-254 (1990).

25. Rashid, A., Rafique, E. \& Bughio, N. Micronutrient deficiencies in rainfed calcareous soils of pakistan. III. Boron nutrition of sorghum. Commun. Soil. Sci. Plant. Anal. 28, 441-454 (1997).

26. Niaz, A., Hannan, A. \& Waqas, M. Boron Status of Soils as Affected by Different Soil Characteristics-pH, $\mathrm{CaCO}_{3}$, Organic Matter and Clay Contents. Pak. J. Agri. Sci. 44, 428-435 (2007).

27. Moheyuddin, K., Salahuddin, J., Mari, aH. \& Panhwar, R. N. Effect of Zinc and Boron Fertilizers Application on Some Physicochemical Attributes of Five Rice Varieties Grown in Agro-Ecosystem of Sindh, Pakistan. Am. J. Agric. Environ. Sci. 13, 433-439 (2013)

28. Sönmez, İ., Kaplan, M. \& Sönmez, S. An investigation of seasonal changes in nitrate contents of soils and irrigation waters in greenhouses located in antalya-demre region. Asian J. Chem. 19, 5639-5646 (2007).

29. Khan, N. et al. Physical and chemical properties of biochars co-composted with biowastes and incubated with a chicken litter compost. Chemosphere 142, 14-23 (2016).

30. Woolf, D., Lehmann, J. \& Lee, D. R. Optimal bioenergy power generation for climate change mitigation with or without carbon sequestration. Nat. Commun. 7, 13160 (2016).

31. Liang, B. et al. Black carbon increases cation exchange capacity in soils. Soil. Sci. Soc. Am. J. 70, 1719 (2006).

32. ASTM Standard. Standard test method for chemical analysis of wood charcoal. American Society for Testing and Materials, Conshohocken, PA (2009).

33. Shi, R. Y. et al. Mechanisms for increasing the $\mathrm{pH}$ buffering capacity of an acidic ultisol by crop residue-derived biochars. J. Agric. Food Chem. 65, 8111-8119 (2017).

34. Abid, M. et al. Biochar increased photosynthetic and accessory pigments in tomato (Solanum lycopersicum L.) plants by reducing cadmium concentration under various irrigation waters. Environ. Sci. Pollut. Res. 24, 22111-22118 (2017).

35. Younis, U. et al. Growth, survival, and heavy metal ( $\mathrm{Cd}$ and Ni) uptake of spinach (Spinacia oleracea) and fenugreek (Trigonella corniculata) in a biochar-amended sewage-irrigated contaminated soil. J. Plant. Nutr. Soil. Sci. 178, 209-217 (2015).

36. Yuan, J. H., Xu, R. K. \& Zhang, H. The forms of alkalis in the biochar produced from crop residues at different temperatures. Bioresour. Technol. 102, 3488-3497 (2011). 
37. Rizwan, M. et al. Mechanisms of biochar-mediated alleviation of toxicity oftrace elements in plants: a critical review. Environ. Sci. Pollut. Res. 23, 2230-2248 (2016).

38. Hopkins, B. \& Ellsworth, J. Phosphorus availability with alkaline/calcareous soil. In Western Nutrient Management Conference 88-93 (2005).

39. Dorozhkin, S. V. Dissolution mechanism of calcium apatites in acids: A review of literature. World J. Methodol. 2, 1-17 (2012).

40. Danish, S. et al. Phosphorus solubilizing bacteria and rice straw biochar consequence on maize pigments synthesis. Int. J. Biosci. 5, 31-39 (2015)

41. Silber, A., Levkovitch, I. \& Graber, E. R. PH-dependent mineral release and surface properties of cornstrawdbiochar: agronomic implications. Environ. Sci. Technol. 44, 9318-9323 (2010).

42. Paz-Ferreiro, J., Gascó, G., Gutiérrez, B. \& Méndez, A. Soil biochemical activities and the geometric mean of enzyme activities after application of sewage sludge and sewage sludge biochar to soil. Biol. Fertil. Soils 48, 511-517 (2012).

43. Laird, D. A. et al. Impact of biochar amendments on the quality of a typical Midwestern agricultural soil. Geoderma 158, 443-449 (2010).

44. Ding, Y. et al. Biochar to improve soil fertility. A review. Agron. Sustain. Dev. 36, 36 (2016).

45. Chapman, H. D. \& Pratt, P. F. Methods of analysis for soils, plants and water. (1961).

46. Jones, J. B., WolfH, B. \& Mills, H. A. Plant Analysis Handbook: A Practical Sampling, Preparation, Analysis, and Interpretation Guide. (Micro-Macro Publishing Inc., 1991).

47. Nadeem, F. et al. Qualitative and Chemical Analysis of Rice Kernel to Time of Application of Phosphorus In Combination With Zinc Under Anaerobic Conditions. Asian J. Agric. Biol. 1, 67-75 (2013).

48. Van Schouwenberg, J. C. \& Walinge, I. Methods of Analysis for Plant Material. (Agricultural University Wageningen, 1973).

49. Danish., S. et al. Effect of foliar application of $\mathrm{Fe}$ and banana peel waste biochar on growth, chlorophyll content and accessory pigments synthesis in spinach under chromium (IV) toxicity. Open. Agri. 4, 381-390 (2019).

50. Noor, N. M., Shariff, A. \& Abdullah, N. Slow Pyrolysis of Cassava Wastes for Biochar Production and Characterization. Iran. J. Energy Env. 3, 60-65 (2012).

51. Schofield, R. K. \& Taylor, A. W. The measurement of soil pH. Soil. Sci. Soc. Am. Proc. 19, 164-167 (1995).

52. US Salinity Laboratory Staff. In Diagnosis and Improvement of Saline and Alkali Soils (Agric. Handbk. 60.US Government Printing Office, 1954).

53. Olsen, S. R. \& Sommers, L. E. Phosphorus. In Method of soil analysis, Agron. No. 9, part 2: Chemical and microbiological properties (ed. Page, A. L.) 403-430 (American Society of Agronomy, 1982).

54. Bingham, F. T. Boron. In Methods of Soil Analysis, Part 2 437-447 (Agron. Monogr. No. 9. ASA and SSSA, 1982).

55. Lindsay, W. L. \& Norvell, W. Aa DTPA soil test for zinc, iron, manganese and copper. Soil. Sci. Soc. Am. 42, 421-428 (1978).

56. Steel, R. G., Torrie, J. H. \& Dickey, D. A. Principles and Procedures of Statistics: A Biometrical Approach. (McGraw Hill Book International Co., 1997).

\section{Author contributions}

S.D. performed research, prepared biochar, collected data and write manuscript; N.A. designed the experiment and completed the manuscript writing; H.S. helped in manuscript improvement and revision; M.M. helped in characterization of biochar and acidified activated carbon.

\section{Competing interests}

The authors declare no competing interests.

\section{Additional information}

Correspondence and requests for materials should be addressed to S.D.

Reprints and permissions information is available at www.nature.com/reprints.

Publisher's note Springer Nature remains neutral with regard to jurisdictional claims in published maps and institutional affiliations.

Open Access This article is licensed under a Creative Commons Attribution 4.0 International

License, which permits use, sharing, adaptation, distribution and reproduction in any medium or format, as long as you give appropriate credit to the original author(s) and the source, provide a link to the Creative Commons license, and indicate if changes were made. The images or other third party material in this article are included in the article's Creative Commons license, unless indicated otherwise in a credit line to the material. If material is not included in the article's Creative Commons license and your intended use is not permitted by statutory regulation or exceeds the permitted use, you will need to obtain permission directly from the copyright holder. To view a copy of this license, visit http://creativecommons.org/licenses/by/4.0/.

(C) The Author(s) 2020 